\title{
Decomposition dynamics and structural plant components of genetically modified $B t$ maize leaves do not differ from leaves of conventional hybrids
}

\author{
Corinne Zurbrügg · Linda Hönemann • \\ Michael Meissle $\cdot$ Jörg Romeis $\cdot$ Wolfgang Nentwig
}

Received: 26 January 2009/ Accepted: 26 June 2009/Published online: 17 July 2009

(C) Springer Science+Business Media B.V. 2009

\begin{abstract}
The cultivation of genetically modified $B t$ maize has raised environmental concerns, as large amounts of plant residues remain in the field and may negatively impact the soil ecosystem. In a field experiment, decomposition of leaf residues from three genetically modified (two expressing the Cry1Ab, one the Cry3Bb1 protein) and six nontransgenic hybrids (the three corresponding nontransformed near-isolines and three conventional hybrids) was investigated using litterbags. To elucidate the mechanisms that cause differences in plant decomposition, structural plant components (i.e., C:N ratio, lignin, cellulose, hemicellulose) were examined. Furthermore, Cry $1 \mathrm{Ab}$ and $\mathrm{Cry} 3 \mathrm{Bb} 1$ protein concentrations in maize leaf residues were measured from harvest to the next growing season. While leaf residue decomposition in transgenic and non-transgenic plants was similar, differences among conventional cultivars were evident. Similarly, plant components among conventional hybrids differed
\end{abstract}

C. Zurbrügg $(\varangle) \cdot$ L. Hönemann · W. Nentwig Institute of Ecology and Evolution, University of Bern, Baltzerstrasse 6, 3012 Bern, Switzerland

e-mail: corinne.zurbruegg@agridea.ch

M. Meissle $\cdot$ J. Romeis

Agroscope Reckenholz-Tänikon Research Station ART, Reckenholzstrasse 191, 8046 Zurich, Switzerland

Present Address:

C. Zurbrügg

AGRIDEA, Eschikon 28, 8315 Lindau, Switzerland more than between transgenic and non-transgenic hybrids. Moreover, differences in senescent plant material collected directly from plants were larger than after exposure to soil for 5 months. While the concentration of Cry3Bb1 was higher in senescent maize leaves than that of Cry1 Ab, degradation was faster, indicating that $\mathrm{Cry} 3 \mathrm{Bb} 1$ has a shorter persistence in plant residues. As decomposition patterns of $B t$-transgenic maize were shown to be well within the range of common conventional hybrids, there is no indication of ecologically relevant, adverse effects on the activity of the decomposer community.

Keywords Bacillus thuringiensis .

$\mathrm{Cry} 1 \mathrm{Ab} \cdot \mathrm{Cry} 3 \mathrm{Bb} 1 \cdot$ Environmental risk assessment . Plant litter $\cdot$ Soil ecosystem

\section{Introduction}

Insect-resistant transgenic maize expressing Cry proteins derived from the bacterium Bacillus thuringiensis $(B t)$ has been grown in steadily increasing amounts in the recent years (James 2007). Hybrids expressing Cry1 proteins have been commercialized to control stem-boring Lepidoptera, and Cry3-expressing hybrids are protected against corn rootworms (Coleoptera: Chrysomelidae). Bt maize provides substantial benefits, e.g., decreased yield losses to pests, reduced need for insecticides, and improved food safety due to lower levels of mycotoxins (Hellmich et al. 2008). 
However, one concern raised with the planting of insecticidal transgenic crops is the potential risk to non-target organisms, including biocontrol organisms, pollinators, decomposers, and protected species (Romeis et al. 2008). Cry protein can enter the soil from roots or from plant residues remaining on the field after harvest (Saxena et al. 1999; Zwahlen et al. 2003; Baumgarte and Tebbe 2005), resulting in continuous exposure of soil organisms to the $B t$ proteins. The present study focuses on decomposition as one major function in sustainable agroecosystems.

For estimating the potential exposure of soil organisms, it is important to know how long Cry proteins persist in the soil. This depends on the rate of microbial activity (e.g., Crecchio and Stotzky 1998, 2001; Tapp and Stotzky 1998), and is correlated with the decomposition of plant material (Zwahlen et al. 2003). In a Swiss field study, Cry proteins have been shown to degrade in the plant material, but traces have been detected for at least 9 months after harvest and were detectable as long as plant material remained (Zwahlen et al. 2003). Persistence also depends on the nature of the Cry protein, as shown by Icoz et al. (2008) who detected Cry1Ab but not Cry3Bb1 in rhizosphere soil over four consecutive years of $B t$ maize cultivation. Furthermore, environmental factors, such as soil composition, $\mathrm{pH}$ and temperature, may have a strong impact on decomposition rates (Icoz and Stotzky 2008). Changes in plant composition of $B t$ crops compared to conventional hybrids could modify the activity of soil organisms and consequently influence the decomposition of plant residues. Slower decomposition rates and thus nutrient cycling could result in nutrient limitation for plants and accumulation of biomass in the soil. This may lead to the accumulation of Cry proteins and, consequently, higher exposure of soil organisms to these proteins. On the other hand, the accumulation of organic material might improve soil structure and reduce erosion.

Earlier studies have focused on differences in decomposition and plant composition between $B t$ maize and corresponding near-isolines and such studies were usually done in one field only. Our aim was to compare the decomposition of different $B t$ and non- $B t$ hybrids and Cry proteins under the conditions of Central Switzerland in a landscape approach. By including ten fields from ten farmers we measured the variation within a whole landscape which is more likely to allow generalizations of the derived results. The decomposition dynamics of leaf residues and the structural plant composition of three $B t$ maize hybrids, their three corresponding nontransformed near-isolines and three conventional hybrids that are commonly grown in Switzerland were compared in the present field study. This approach allowed us to interpret significant differences between a given $B t$ hybrid and its corresponding near-isolines in the context of variation among commonly grown conventional hybrids which are generally regarded as having no unacceptable environmental impacts. Characteristic degradation patterns of different Cry proteins were addressed by using two hybrids expressing Cry1 $\mathrm{Ab}$ and one expressing Cry3Bb1. Decomposition of leaf residues exposed to soil in litterbags was measured from harvest to the beginning of the next planting season. $\mathrm{C}: \mathrm{N}$ ratios and structural plant components (cellulose, hemicellulose, and lignin) that are relevant for decomposition were examined. Using enzyme-linked immunosorbent assays and sensitive insect bioassays, the bioactivity of Cry1 Ab and Cry3Bb1 in decaying leaf residues was analyzed. Leaf residue decomposition and degradation of Cry proteins were correlated with soil temperature.

\section{Materials and methods}

Plant cultivation

The nine maize hybrids used for the experiment included three $B t$-transgenic hybrids, three corresponding non-transformed near-isolines, and three conventional maize hybrids commonly planted in Switzerland (Table 1). Plants were grown in a climate chamber $\left(16: 8 \mathrm{~h}\right.$ light:dark at 25 and $20^{\circ} \mathrm{C}$, respectively), in plastic pots $\left(\begin{array}{ll}18 & 1\end{array}\right)$ filled with geranium and balcony plant soil (Mioplant, Switzerland). Before sowing, $35 \mathrm{~g}$ long-term fertilizer (14\% $\mathrm{N}, 7 \% \mathrm{P}, 14 \% \mathrm{~K}, 1.5 \% \mathrm{Mg}$, Hauert, Switzerland) was added to each pot. Four plants were grown in each pot with five pots per hybrid. Each pot was fertilized once a week with 0.51 of $0.2 \%$ liquid fertilizer $(10 \% \mathrm{~N}, 10 \% \mathrm{P}, 7.5 \% \mathrm{~K}, 1.24 \% \mathrm{~B}$, Maag Agro, Switzerland). Leaves were cut when senescent after about 12 weeks and stored at $-25^{\circ} \mathrm{C}$ until used for the experiment. 
Table 1 Maize hybrids used for the experiment

\begin{tabular}{lllll}
\hline Hybrid & Event & Trait & $\begin{array}{l}\text { Bt } \\
\text { Protein }\end{array}$ & Company \\
\hline N4640Bt & Bt11 & Bt & Cry1Ab & $\begin{array}{l}\text { Syngenta, } \\
\text { Switzerland } \\
\text { N4640 }\end{array}$ \\
& & iso & & $\begin{array}{l}\text { Syngenta, } \\
\text { Switzerland }\end{array}$ \\
Novelis & MON810 & Bt & Cry1Ab & Monsanto, USA \\
Nobilis & & iso & & Monsanto, USA \\
DKC5143Bt & MON88017 & Bt & Cry3Bb1 & Monsanto, USA \\
DKC5143 & & iso & & Monsanto, USA \\
LG22.65 & & con & & UFA, \\
& & & & Switzerland \\
LG22.75 & & con & & UFA, \\
& & & & Switzerland \\
Birko & & con & & UFA, \\
& & & & Switzerland \\
\hline
\end{tabular}

$\overline{B t}$, Bt-transgenic; iso, corresponding non-transformed nearisoline; con, conventional maize hybrid

\section{Litterbag field experiment}

Ten maize fields near Worb (Swiss Plateau) were chosen for the field experiment. After maize had been harvested in early autumn 2005, winter barley or wheat was planted by the farmers. Half of the field soils were characterized as loam and the other half as sandy loam; $\mathrm{pH}$ varied between 6.0 and 7.2; humus content was between 3.5 and 7\% (Schweizer Labor für Umwelttechnik, Switzerland). Litterbags made of polyethylene mesh $(15 \times 15 \mathrm{~cm}, 4 \mathrm{~mm}$ mesh size $)$ were filled with $3.5 \mathrm{~g}$ dry weight of senescent leaves of one maize hybrid cut in about $10 \mathrm{~cm}$ long strips. In October 2005, nine bags per hybrid were buried in a horizontal position at a depth of $5 \mathrm{~cm}$ in each field. Litterbags were arranged in nine circles $(2 \mathrm{~m}$ diameter) per field with each circle containing one bag of each of the nine hybrids. These circles were spaced $0.5 \mathrm{~m}$ apart and were at least $20 \mathrm{~m}$ from the field border. Soil temperature was measured in two fields during the sampling period with two data loggers at a depth of $5 \mathrm{~cm}$. Litterbags were collected from one circle per field every month from November 2005 to June 2006, resulting in ten litterbags per hybrid and sampling date, with the following exceptions: Since there was not enough harvested leaf material for all sampling occasions, no bags of Novelis were buried for the February, May, and June samples and none of
Birko for the February sample. Nobilis was buried in eight fields only and was sampled in November, December, February, March, and June. When collected from the field sites, litterbags were placed separately in plastic bags to avoid loss of plant material. In the laboratory, they were opened, and about $1 / 4$ of the plant material was removed and frozen at $-25^{\circ} \mathrm{C}$ for subsequent laboratory analyses. The remaining plant material was used for identification and analysis of the soil invertebrate community (Hönemann et al. 2008). To assess the decomposition of maize litter, plant material used for the laboratory analyses and the part from which soil fauna was extracted, was rinsed with deionized water to remove soil particles and roots, dried at $40^{\circ} \mathrm{C}$ for $72 \mathrm{~h}$ and weighed.

Analysis of C:N ratio, cellulose, hemicellulose and lignin

$\mathrm{C}: \mathrm{N}$ ratios were analyzed in senescent leaves cut directly from the plants (10 samples per maize hybrid, 10 randomly chosen leaves from different plants per sample) and from the litterbags collected from the fields in March (one sample per hybrid and field). All samples were dried at $40^{\circ} \mathrm{C}$ for $72 \mathrm{~h}$ and ground in an ultra centrifugal mill (ZM 1, Retsch, Germany). After adding a $5 \mathrm{~mm}$ tungsten carbide ball, subsamples were pulverized for $2 \mathrm{~min}$ at $30 \mathrm{~Hz}$ in a mixer mill (MM300, Retsch, Germany) fitted with 24 tube-adapters for $2 \mathrm{ml}$ microreaction tubes (Qiagen, Switzerland). Total carbon and nitrogen contents were determined with a Euro EA300 Elemental Analyzer (HEKAtech GmbH, Germany) using samples of 6-12 mg leaf dry weight. Calculations were done using the Callidus ${ }^{\mathrm{TM}}$ 2E3 Software (HEKAtech GmbH, Germany).

Cellulose, hemicellulose and lignin contents were analyzed for senescent leaves cut directly from the plants (five samples per maize hybrid) and from litterbags collected in March (five samples per hybrid). After drying and grinding (see above), samples were analyzed by FOOD GmbH (Jena, Germany). The neutral detergent fiber (NDF) method was used for the determination of hemicellulose, cellulose and lignin, and the acid detergent fiber (ADF) method for the determination of cellulose and lignin. The ADF method was followed by the acid detergent lignin (ADL) method to determine cellulose 
and lignin content separately. Hemicellulose content was calculated by subtracting ADF from NDF (VDLUFA 1976).

\section{Cry protein analysis}

Cry1 Ab protein concentrations in leaves were quantified using an enzyme-linked immunosorbant assay (ELISA) (Gugerli 1979, 1986). For Cry3Bb1 protein analysis, a PathoScreen kit (Agdia, USA) was modified for quantitative measurement (see below). Both tests do not only measure intact Cry proteins but also fractions of the proteins that are amenable to detection by the ELISA. Three leaf samples each weighing about $20 \mu \mathrm{g}$, were analyzed from each litterbag. Samples were washed with deionized $\mathrm{H}_{2} \mathrm{O}$ to remove soil particles, lyophilized, and homogenized in $5 \mathrm{ml}$ of extraction buffer in an extraction bag (type universal, Bioreba, Switzerland). After centrifugation for $10 \mathrm{~min}$ at $600 \mathrm{~g}$, supernatants were diluted 20-fold for Cry1 Ab and 50-fold for Cry3Bb1 analysis. To construct a calibration curve, reference samples of purified Cry1Ab protein (M. PusztaiCarey, Case Western Reserve University, USA) were suspended in pooled extracts of control leaves (N4640, Nobilis) at concentrations between 0.2 and $50 \mathrm{ng}$ protein $/ \mathrm{ml}$. For Cry3Bb1, purified protein (Agdia) was suspended in phosphate buffered saline Tween-20 buffer (Agdia) and seven concentrations between 0.313 and $20 \mathrm{ng}$ protein/ml were prepared. Optical density was measured at 405 and $630 \mathrm{~nm}$ for the $\mathrm{Cry} 1 \mathrm{Ab}$ and $\mathrm{Cry} 3 \mathrm{Bb} 1$ protein, respectively. Concentrations of calibrators and measured optical densities were log-transformed, and a linear regression was carried out to calculate the $B t$ protein concentrations (GraphPad Software Inc. 2000), which are presented in microgram Cry protein per gram dry weight of leaf tissue.

\section{Sensitive insect bioassays}

The insecticidal activity of Cry1Ab was tested in a bioassay using neonate larvae of Ostrinia nubilalis (Lepidoptera: Crambidae, egg masses obtained from French Agricultural Research Inc., USA). Senescent leaves of N4640Bt, Novelis, and their untransformed near-isolines were used, either cut directly from maize plants or retrieved from litterbags collected in the field in December and February. Leaves from the same maize hybrid per sampling date were ground in an ultra centrifugal mill (Retsch Technology $\mathrm{GmbH}$, Germany). For bioassays, $15 \%$ of leaf powder (w/w; based on dry weight) was mixed in the artificial diet for $O$. nubilalis. The diet consisted of $42.5 \mathrm{ml}$ water, $1.25 \mathrm{~g}$ agar-agar, and $2.66 \mathrm{~g}$ each of maize semolina, wheat germ and Torula yeast (Bathon et al. 1991). Using ELISA, the presence of Cry $1 \mathrm{Ab}$ in maize semolina was excluded before using it in the artificial diet. After solidification, $0.5 \mathrm{ml}$ of diet and ten neonate larvae were placed into each of ten vials (53 mm height and $22 \mathrm{~mm}$ diameter) per treatment. Vials were closed with parafilm and kept in a climate chamber at a constant temperature of $25^{\circ} \mathrm{C}(16: 8 \mathrm{~h}$ light:dark). Mortality of larvae was recorded after 6 days.

The insecticidal activity of Cry3Bb1 was confirmed using larvae of the Colorado potato beetle, Leptinotarsa decemlineata (Coleoptera: Chrysomelidae) (Meissle and Romeis 2009). Eggs were obtained from the Alampi Beneficial Insect Laboratory (State of New Jersey, Department of Agriculture, USA). Leaf material was pulverized as described above and $20 \%$ (w/w) was mixed into Colorado potato beetle artificial diet (Bio-Serv, USA). Small cubes (ca. $0.24 \mathrm{~cm}^{3}$ ) of solidified diet were placed individually into the wells of 128-well bioassay trays (Bio-Serv) and one neonate larva of $L$. decemlineata was added per well. The trays were closed with ventilated lids (Bio-Serv). After 7 days at $25^{\circ} \mathrm{C}$ (16:8 h light:dark), mortality of larvae was recorded. Each treatment was replicated with 40 larvae.

\section{Data analyses}

Analyses were conducted in R 2.3.1 (R Development Core Team 2006) and SPSS 13.0. Differences in leaf residue decomposition of the nine maize hybrids over the 9 months were analyzed using a linear mixed effect model (LME) with the lme function using the package "nlme" (Pinheiro et al. 2006). LME's are useful in cases where there is temporal pseudoreplication as in this case the monthly sampling of the same fields. Month and maize hybrid were fitted as explanatory variables. To control for the sampling of the same fields, maize hybrid was nested within field and fitted as a random factor. Differences in C:N ratio, cellulose, hemicellulose, and lignin content among 
maize hybrids were analyzed using one-way ANOVA followed by Tukey HSD multiple comparison post hoc test. A LME with $B t$ protein concentrations of the three maize hybrids over the 9 months was carried out. Month, $B t$ maize hybrid, and the interaction of both were fitted as explanatory variables. The repeated sampling in the same field was controlled with field subject fitted as a random factor (maize hybrid nested within field). The dependent variable, $B t$ protein concentration, was log-transformed to meet model assumptions. The significance of differences in mortality of $O$. nubilalis in the sensitive insect bioassay was tested with independent sample $t$-tests. Mortality was arcsin-transformed to achieve normal distribution of data and homogeneity of variance. Differences in mortality of $L$. decemlineata were analyzed using Chi-square tests.

\section{Results}

Decomposition of leaf residues

Decomposition varied significantly among maize hybrids $\left(F_{8,70}=4.2, \quad P<0.0001\right)$ and decreased over time $\left(F_{8,617}=1614.2, P<0.0001\right.$; Fig. 1a). Differences among hybrids were most apparent from December to March. Furthermore, leaf residue decomposition differed significantly among the three transgenic hybrids $\left(F_{2,18}=8.6, P=0.0024\right)$ and among the six conventional hybrids $\left(F_{5,43}=3.5, P=0.009\right)$. However, no differences between transgenic maize hybrids and their corresponding near-isolines were found $(P>0.05)$. In June, no differences among hybrids were visible. The standard deviation of the random factor field (0.139) was larger than the standard deviation of the maize hybrids on the same field $\left(8.25 \mathrm{E}^{-6}\right)$, indicating that differences among fields were larger than differences among maize hybrids. From October to November, about $30 \%$ of the initial leaf residues were degraded, whereas only $10 \%$ were degraded from November to the end of February while the soil was frozen (Fig. 1b). From the end of March until June, there was a strong increase in decomposition of leaf residues correlated with increasing temperature. At the end of June, only the mid-ribs of the maize leaves were left, representing about $10 \%$ of the initial mass of leaf residues.
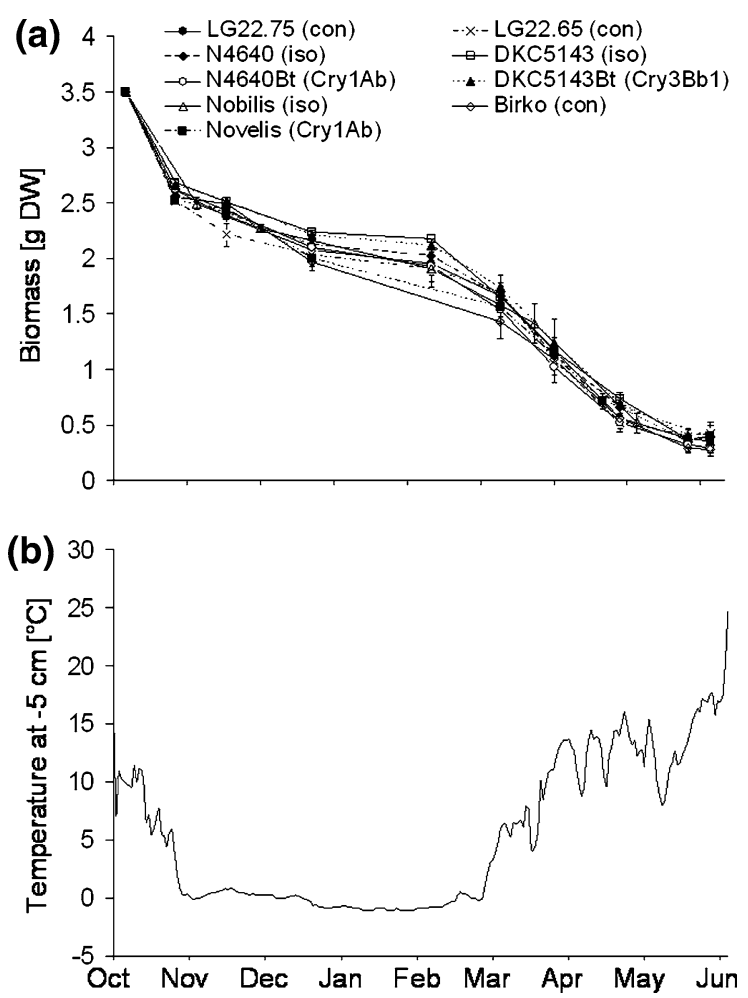

Fig. 1 a Leaf residue decomposition (mean $\pm S E$ ) of three conventional maize varieties (con), three transgenic (Cry1Ab, Cry3Bb1) and their three corresponding non-transformed near isolines (iso) from October 2005 to June 2006. $N=10$ per hybrid and sampling date. DW indicates dry weight. b Average daily soil temperature $\left({ }^{\circ} \mathrm{C}\right)$ at $5 \mathrm{~cm}$ depth from October 2005 to June 2006

$\mathrm{C}: \mathrm{N}$ ratio and content of cellulose, hemicellulose and lignin

$\mathrm{C}: \mathrm{N}$ ratios differed significantly among the nine maize hybrids in senescent leaves collected directly from the plant $\left(F_{8,89}=15.9, P<0.0001\right.$; Fig. $2 \mathrm{a}$; white boxes). The transgenic hybrids, Novelis and DKC5143Bt, had a lower (both $P<0.0001$ ), and N4640Bt a higher $(P=0.014) \mathrm{C}: \mathrm{N}$ ratio compared with their respective corresponding near-isoline. However, differences among non-transgenic hybrids were also significant. Differences among hybrids were still present in plant material collected from the fields in March $\left(F_{8,87}=2.1, P=0.045\right.$; Fig. 2a; grey boxes). However, none of the transgenic hybrids differed from their corresponding near-isolines.

Cellulose $\left(F_{8,44}=8.4, P<0.001\right)$, hemicellulose $\left(F_{8,44}=4.7, P<0.001\right)$, and lignin $\left(F_{8,44}=4.3\right.$, $P<0.001)$ in senescent leaves differed among the 

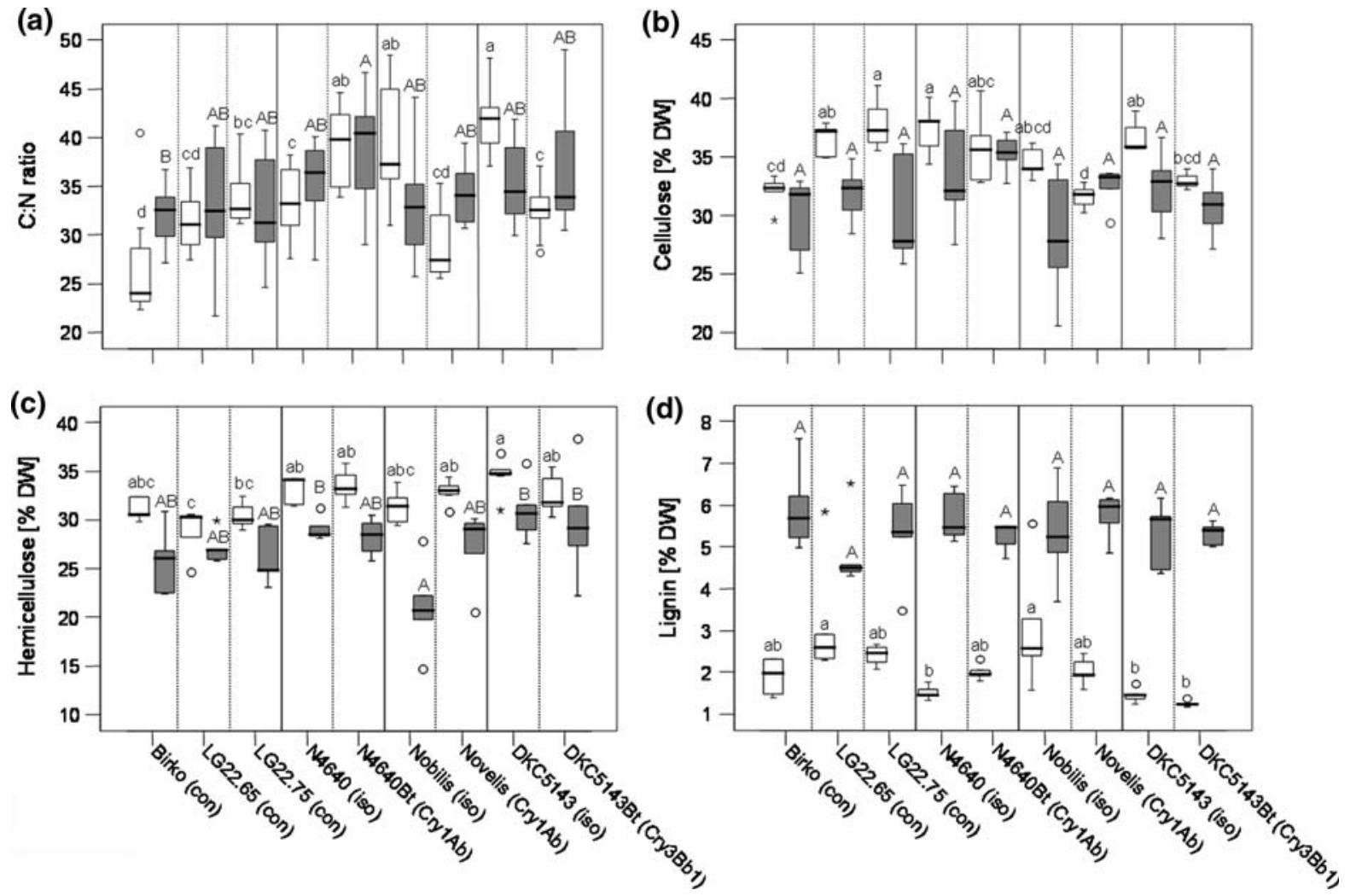

Fig. 2 Boxplots of a C:N ratio, b cellulose, $\mathbf{c}$ hemicellulose and d lignin content in leaves from three conventional maize varieties, three $B t$-transgenic varieties and their non-transformed counterparts. White boxes refer to leaf samples cut directly from maize plants, and grey boxes to litterbag samples collected from the field in March (after 5 months buried in the soil). Boxes describe the interquartile range $(I Q R)$ from the first to the third quartile. Circles indicate outliers (observations that lie more than 1.5 IQR lower or higher than the first or third

nine maize hybrids when collected directly from the plants (Fig. 2b-d; white boxes). The genetically modified hybrids were never different from their corresponding near-isolines, but significant differences were found among conventional hybrids. In plant material from litterbags collected in March, only hemicellulose content differed among the nine maize hybrids $\left(F_{8,44}=3.3, P=0.006\right.$; Fig. $2 \mathrm{c}$; grey boxes). Again, conventional hybrids differed from each other, while transgenic and non-transgenic plants were similar.

\section{Degradation of $B t$ proteins}

Analyses of the plant material derived from the litterbags collected from the fields revealed that the quartile, respectively), and asterisks indicate far outliers (more than 3 IQR higher or lower the first and third quartile). Whiskers refer to the highest or smallest observation that is not an outlier. Different letters above the boxes (small letters for fresh plant material; capital letters for litterbag samples) indicate significant differences between maize varieties (Tukey test, $P<0.05$ ). $N=10$ per hybrid for $\mathrm{C}: \mathrm{N}$ ratio and $N=5$ per hybrid for cellulose, hemicellulose, and lignin content. DW indicates dry weight

degradation curves of the different hybrids differed over the study period (hybrid: $F_{2,18}=46.3$, $P<0.0001$, month: $F_{6,160}=613.7, \quad P<0.0001$, hybrid * month: $\left.F_{12,160}=50.3, \quad P<0.0001\right)$. In DKC5143Bt, $48 \%$ of Cry3Bb1 in senescent leaves was degraded after 3 weeks, and $95 \%$ was degraded after 6 weeks (Fig. 3). In January, $<1 \mu \mathrm{g} / \mathrm{g}$ dry weight from the initial $55 \mu \mathrm{g} / \mathrm{g}$ dry was detected. In N4640Bt, $40 \%$ of Cry1 Ab was degraded after 3 weeks and 55\% after 6 weeks; in January, $40 \%$ $(6.1 \pm 2.29 \mu \mathrm{g} / \mathrm{g})$ of the initial concentration remained. In Novelis, no Cry1 $\mathrm{Ab}$ had degraded within the first 3 weeks, and after 6 weeks, only $20 \%$ had degraded. In January, 60\% $(7.5 \pm 2.33 \mu \mathrm{g} /$ g) of the initial protein concentration remained. However, at the end of June, more than $99 \%$ of the 
Cry proteins had degraded in leaf material of all three transgenic maize hybrids, resulting in concentrations of $<1 \mu \mathrm{g} / \mathrm{g}$ dry weight. During winter, when the soil was frozen, concentrations of $\mathrm{Cry} 1 \mathrm{Ab}$ remained relatively constant, whereas Cry3Bb1 concentrations decreased further. As soil temperature increased in March, degradation of Cry1 Ab resumed. The limit of detection for the Cry1 $\mathrm{Ab}$ and Cry3Bb1 protein in leaf residues was $0.14 \mu \mathrm{g} / \mathrm{g}$ dry weight and $0.06 \mu \mathrm{g} / \mathrm{g}$ dry weight, respectively, as calculated by leaf extracts of the corresponding non-transgenic isolines. No $B t$ protein was detected in leaf material from any of the non-transgenic maize hybrids.

\section{Susceptible herbivore bioassay}

The mortality of neonate $O$. nubilalis was higher when reared on a diet containing N4640Bt or Novelis leaves cut directly from senescent plants or derived from litterbags collected in December than when reared on non-Bt leaves (Fig. 4). No lethal effect was observed when larvae were fed on a diet containing $B t$ leaf residues collected from the field in February.

The mortality of $L$. decemlineata was higher when fed a diet containing DKC5143Bt leaves cut directly from senescent plants or derived from litterbags collected in December compared with the control diets. No differences were found when larvae were fed on a diet containing ground $B t$ leaf residues collected in February.

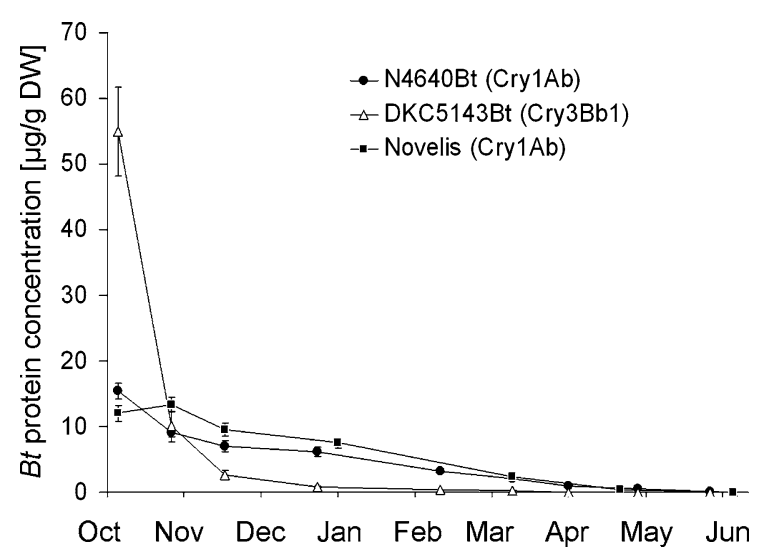

Fig. $3 B t$ protein concentrations (mean \pm SE) in senescent leaves of the $B t$ maize varieties Novelis, N4640Bt, and DKC5143Bt in field litterbags over 9 months. Black symbols refer to the two varieties expressing Cry $1 \mathrm{Ab}$ protein, the white symbol to the hybrid expressing Cry3Bb1 protein. $N=10$ per hybrid and sampling date. DW indicates dry weight

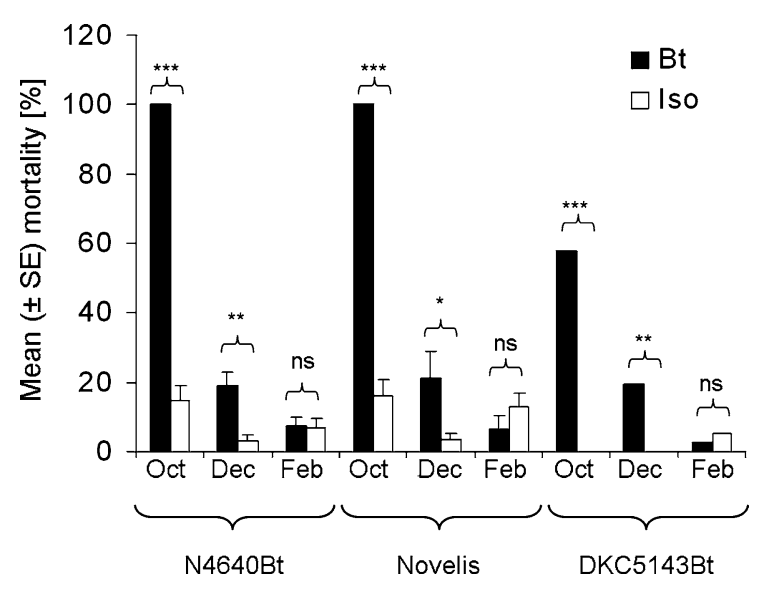

Fig. 4 Mean $( \pm$ SE) mortality $(\%)$ of Ostrinia nubilalis or Leptinotarsa decemlineata reared on leaf litter from three $B t$ maize hybrids and their corresponding non-transformed nearisolines (Iso) from different sampling dates (leaf powder incorporated into artificial diet). Plant material from October samples was collected directly from senescent plants. Bars with asterisks represent significant differences: $*$ for $P<0.05$, ** for $P<0.01$, *** for $P<0.001, n s$ not significant

\section{Discussion}

The decomposition of maize leaf residues in the field differed among hybrids and was slow during winter when the soil was frozen. This indicates that temperature has a major influence on decomposition, most probably due to the correlation between microbial activity and temperature. Decomposition was similar for $B t$ maize hybrids and their corresponding non-transformed near-isolines, but differed among transgenic hybrids and among conventional hybrids. These results are in line with previous litterbag studies reporting no overall differences between decomposition rates of $B t$ and non- $B t$ maize (Zwahlen et al. 2003, 2007; Lehman et al. 2008; Tarkalson et al. 2008). Similarly, microcosm studies with pulverized plant material in soil revealed no difference in $\mathrm{CO}_{2}$ emission and thus decomposition between $\mathrm{Bt}$ and control maize (Hopkins and Gregorich 2003). In another microcosm study, however, Flores et al. (2005) observed lower $\mathrm{CO}_{2}$ emission in the case of $B t$ plants and attributed this to the higher lignin content in the $B t$ plants used. A higher lignin content in leaves and stems of $B t$ maize hybrids compared to their corresponding near-isolines was also reported by Saxena and Stotzky (2001) and Poerschmann et al. (2005). However, differences in 
plant components in the present study are not systematically related to the expression of Cry proteins.

Interestingly, there were no differences in the tested plant components between any transgenic hybrid and the corresponding near-isoline in leaf samples collected from the field in March. Lower lignin content and $\mathrm{C}: \mathrm{N}$ ratios and higher levels of soluble carbohydrates were found in leaves of $B t$ maize by Escher et al. (2000) and differences in total $\mathrm{C}$, total $\mathrm{N}$, biomass fractions and $\mathrm{C}: \mathrm{N}$ ratios were reported by Tarkalson et al. (2008). Other studies did not detect differences between $B t$ and non- $B t$ maize composition (Jung and Sheaffer 2004; Lehman et al. 2008; Mungai et al. 2005; Poerschman et al. 2008, 2009). The composition of a transgenic hybrid and the corresponding non-transformed near-isoline are likely to differ to some extent due to genetic differences between the hybrids (Motavalli et al. 2004). Although near-isolines show the highest genetic similarity to the $B t$ hybrid, the $B t$ trait has to be introduced into the conventional hybrid after transformation. This requires several steps of selection and breeding, resulting in genetic differences in the range of those obtained by conventional breeding. In summary, $B t$ maize hybrids may or may not differ from their nearisolines in structural plant components, but even when differences are present, this does not necessarily have an effect on decomposition, as demonstrated by our study and by Tarkalson et al. (2008).

Significant differences among conventional hybrids were found for all measured plant components in leaf material collected directly from maize plants. Our results are supported by Poerschman et al. (2008) who found significant differences in total lignin and molecular based lignin patterns in leaves of different conventional maize hybrids whereas no differences between the transgenic line DKC5143Bt and its corresponding near-isoline could be observed. While relatively low $\mathrm{C}: \mathrm{N}$ ratios were found in the rapidly decomposing hybrids Birko, LG22.65, and Novelis, the ratios were higher in the more slowly decomposing hybrid, DKC5143. The fact that plant decomposition is often inversely related to the $\mathrm{C}: \mathrm{N}$ and lignin:N ratio was previously reported by Taylor et al. (1989) and Poerschmann et al. (2005), even though this relationship was not evident in our study on C:N ratios between transgenic hybrids and corresponding near-isolines or in the study by Tarkalson et al.
(2008). In the present study, non-transgenic maize hybrids differed in all plant components and decomposition patterns. In contrast, $B t$ hybrids differed from near-isolines only in $\mathrm{C}: \mathrm{N}$ ratios, while decomposition patterns were similar. This indicates that the $B t$ hybrids assessed in the present study lie well within the range of variation found among commonly used conventional hybrids. Similarly, Tarkalson et al. (2008) reported differences in decomposition between hybrids with different genetic backgrounds, but not in $B t$ and control lines with the same background. However, in the present study, differences between hybrids leveled out with time, as variation in plant components was considerably higher in leaf material collected directly from the plants compared to that after 5 months of field exposure.

The concentration of Cry3Bb1 in senescent maize leaves was about five times higher than that of Cry1Ab. However, Cry3Bb1 degraded faster than $\mathrm{Cry} 1 \mathrm{Ab}$, and continued to degrade when the soil was frozen. Sensitive insect bioassays confirmed the insecticidal activity of both Cry proteins in decaying leaves until December. No differences in mortality were observed when sample material collected in February was incorporated into insect diets. Faster degradation of Cry3Bb1 in the field compared to $\mathrm{Cry} 1 \mathrm{Ab}$ has been reported previously, as Cry1 $\mathrm{Ab}$ was detected in the soil during four consecutive years of Bt maize cultivation, whereas Cry3Bb1 was not detected (Ahmad et al. 2005; Icoz et al. 2008). In addition, Cry1 $\mathrm{Ab}$ released in root exudates and from biomass of $B t$ maize persisted in soil microcosms for at least 180 days and 3 years, respectively (Saxena and Stotzky 2002). In contrast, Cry3Bb1 from root exudates was detected for 14 days, and the persistence in soil amended with biomass was at most 40 days, depending on the type and amount of clay minerals present and on $\mathrm{pH}$ (Icoz and Stotzky 2007). In the current study, Cry1 Ab and Cry3Bb1 were still detectable in partly degraded maize leaves incorporated into the soil after 9 months, even though protein concentrations were less than $1 \mu \mathrm{g} / \mathrm{g}$ dry weight, which is in line with results from Zwahlen et al. (2003) for Cry1Ab. In contrast to the field situation where temperature falls below $0^{\circ} \mathrm{C}$, degradation was shown to be much faster at a constantly high temperature of $24-27^{\circ} \mathrm{C}$ (Sims and Holden 1996). In plant material incorporated into soil, Cry $1 \mathrm{Ab}$ 
degraded by $50 \%$ after 1.6 days, and $90 \%$ after 15 days. When incubated without soil, $50 \%$ of the $B t$ protein degraded after 25.6 days and $90 \%$ after 40.7 days. This indicates that temperature is not only a major factor for the decomposition of plant residues, it also drives the degradation of $B t$ proteins within the plant residues. After 9 months in the present study, only $10 \%$ of the initial biomass was left. Over the same time, both $B t$ protein concentrations in plant residues declined to $<1 \%$ of the initial concentration. For the total amount of $B t$ proteins present in the field, this means that less than $0.1 \%$ ( $B t$ protein concentration $\times$ amount of leaf residues) of the $B t$ protein entering the soil at harvest persists until the following season. The fast decline at the beginning of the degradation process further indicates that non-target organisms in the soil are exposed only for a short time to high Cry protein concentrations.

However, differences in plant composition, and consequently decomposition, as well as the presence of $B t$ protein in the soil may have ecological consequences on the soil fauna in the agro ecosystem. Hönemann et al. (2008) investigated the soil mesoand macro-fauna in the litterbag samples collected from the fields in the present study. Differences in Collembola, Acari and Clitellata were more pronounced between the sampling months and the study fields than between the investigated hybrids, including the $B t$ and non- $B t$ maize pairs. The fact that field type can influence soil organisms and decomposition processes is supported by the present study, as differences in leaf residue decomposition were also larger among study fields than among investigated hybrids. In an earlier study, Zwahlen et al. (2007) reported that species composition was similar in the $B t$ (Cry1 $\mathrm{Ab})$ and non- $B t$ plant samples. Laboratory and field studies showed that exposure to different Cry proteins and the cultivation of various $B t$ maize hybrids did not have a negative effect on woodlice, collembolans, mites, earthworms, nematodes or protozoa (Icoz and Stotzky 2008). Effects on microbial communities were reported to be transient and not related to the presence of the Cry proteins. In contrast, the effects of geography, temperature, plant hybrid and soil type on microbial communities were evident (Icoz and Stotzky 2008). For example, Griffiths et al. $(2005,2007)$ showed that soil microbial community structure, protozoa, nematodes and enzyme activities were similar in $B t$ and control maize while hybrid, management practice and seasonal effects were present. These results indicate that $B t$ maize is comparable to conventional hybrids. Differences between conventional hybrids are generally accepted and are not regarded as ecologically relevant.

\section{Conclusions}

The C:N ratios of $B t$-transgenic hybrids differed from their corresponding non-transformed near-isolines, but more pronounced differences in $\mathrm{C}: \mathrm{N}$ ratio, lignin, cellulose and hemicellulose content were present among conventional cultivars. Consequently, the decomposition dynamics of transgenic hybrids were similar to the non-transgenic near-isolines, but varied among conventional hybrids, demonstrating that $B t$ transgenic maize hybrids lie within the variation found in conventional maize agroecosystems. Expression levels and degradation patterns were different for $\mathrm{Cry} 1 \mathrm{Ab}$ and $\mathrm{Cry} 3 \mathrm{Bb} 1$, but leaf residues and $\mathrm{Bt}$ protein concentration decreased rapidly in all $B t$ maize hybrids. Thus, non-target soil organisms are exposed to relatively low $B t$ protein concentrations within a few months after harvest. The present study gives no indication of deleterious effects of $B t$ maize on the activity of the decomposing community.

Acknowledgments We thank L. Kuhn-Nentwig for technical help in the laboratory and V. Keller and B. Tschanz for assistance in the field. We are thankful to the farmers for providing their fields. H.P Kunc, S. Dubelmann, C. Zwahlen and two anonymous reviewers gave valuable comments on an earlier draft of this article. We thank Monsanto for providing maize seeds and P. Natale and L. French for kindly providing eggs of the Colorado Potato Beetle and the European Corn Borer. We are grateful to $\mathrm{H}$. Bachmann and $\mathrm{F}$. Blum for instructions on the $\mathrm{C} / \mathrm{N}$ analyzer. This project was funded by the Swiss Federal Office for the Environment (FOEN).

\section{References}

Ahmad A, Wilde G, Yan Zhu K (2005) Detectability of coleopteran-specific Cry3Bb1 protein in soil and its effect on nontarget surface and below-ground arthropods. Environ Entomol 34:385-394

Bathon H, Singh P, Clare GK (1991) Rearing methods. In: Van der Geest LPS, Evenhuis HH (eds) Tortricid pests: their biology, natural enemies and control. Elsevier, Amsterdam, pp 283-312

Baumgarte S, Tebbe CC (2005) Field studies on the environmental fate of the Cry $1 \mathrm{Ab} B t$-toxin produced by 
transgenic maize (Mon810) and its effect on bacterial communities in the maize rhizosphere. Mol Ecol 14:2539-2551

Crecchio C, Stotzky G (1998) Insecticidal activity and biodegradation of the toxin of Bacillus thuringiensis subsp. kurstaki bound to humic acids from soil. Soil Biol Biochem 30:463-470

Crecchio C, Stotzky G (2001) Biodegradation and insecticidal activity of the toxin of Bacillus thuringiensis subsp. kurstaki bound on complexes of montmorillonite-humic acidsAI hydroxypolymers. Soil Biol Biochem 33:573-581

Escher N, Käch B, Nentwig W (2000) Decomposition of transgenic Bacillus thuringiensis maize by microorganisms and woodlice Porcellio scaber (Crustacea: Isopoda). Basic Appl Ecol 1:161-169

Flores S, Saxena D, Stotzky G (2005) Transgenic Bt plants decompose less in soil than non- $B t$ plants. Soil Biol Biochem 37:1073-1082

Griffiths BS, Caul S, Thompson J et al (2005) A comparison of soil microbial community structure, protozoa and nematodes in field plots of conventional and genetically modified maize expressing the Bacillus thuringiensis Cry $1 \mathrm{Ab}$ toxin. Plant Soil 275:135-146

Griffiths BS, Caul S, Thompson J et al (2007) Microbial and microfaunal community structure in cropping systems with genetically modified plants. Pedobiologia 51:195206

Gugerli P (1979) Le test immuno-enzymatique (ELISA) et son application pour le diagnostic rapide des viruses de la pomme de terre. Rev Suisse d'Agric 11:253-260

Gugerli P (1986) Potato viruses. In: Bergmeyer HU (ed) Methods of enzymatic analysis, vol XI. VCH Verlagsgesellschaft GmbH, Weinheim, pp 430-446

Hellmich RL, Albajes R, Bergvinson D et al (2008) The present and future role of insect-resistant genetically modified maize in IPM. In: Romeis J, Shelton AM, Kennedy GG et al (eds) Integration of insect-resistant genetically modified crops within IPM programs. Springer, Dordrecht, pp 119-158

Hönemann L, Zurbrügg C, Nentwig W (2008) Effects of Btcorn decomposition on the composition of the soil mesoand macro-fauna. Appl Soil Ecol 40:203-209

Hopkins DW, Gregorich EG (2003) Detection and decay of the $B t$ endotoxin in soil from a field trial with genetically modified maize. Eur J Soil Sci 54:793-800

Icoz I, Stotzky G (2007) Cry3Bb1 protein from Bacillus thuringiensis in root exudates and biomass of transgenic corn does not persist in soil. Trans Res 17:609-620

Icoz I, Stotzky G (2008) Fate and effects of insect-resistant $B t$ crops in soil ecosystems. Soil Biol Biochem 40:559-586

Icoz I, Saxena D, Andow DA, Zwahlen C, Stotzky G (2008) Microbial populations and enzyme activities in soil in situ under transgenic corn expressing Cry proteins from Bacillus thuringiensis. J Environ Qual 37:647-662

James C (2007) Global status of commercialized biotech/GM crops: 2007. ISAAA Brief No. 37, ISAAA, Ithaca, NY

Jung HG, Sheaffer CC (2004) Influence of Bt transgenes on cell wall lignification and digestibility of maize stover for silage. Crop Sci 44:1781-1789

Lehman MR, Osborne SL, Rosentrater KA (2008) No differences in decomposition rates observed between Bacillus thuringiensis and non-Bacillus thuringiensis corn residue incubated in the field. Agron J 100:163-168

Meissle M, Romeis J (2009) Insecticidal activity of Cry3Bb1 expressed in $B t$ maize on larvae of the Colorado potato beetle, Leptinotarsa decemlineata. Ent Exp Appl 131:308-319

Motavalli PP, Kremer RJ, Fang M, Means NE (2004) Impact of genetically modified crops and their management on soil microbially mediated plant nutrient transformation. J Environ Qual 33:816-824

Mungai NW, Motavalli PP, Nelson KA, Kremer RJ (2005) Differences in yields, residue composition and $\mathrm{N}$ mineralization dynamics of $B t$ - and non-Bt-maize. Nutr Cycl Agroecosys 73:101-109

Pinheiro J, Bates D, DebRoy S, Sarkar D (2006) nlme: Linear and nonlinear mixed effect models. $\mathrm{R}$ package version 3.1-73

Poerschman J, Rauschen S, Langer U, Augustin J, Górecki T (2008) Molecular level lignin patterns of genetically modified Bt-maize MON88017 and three conventional varieties using tetramethylammonium hydroxide (TMAH)-induced thermochemolysis. J Agr Food Chem 56:11906-11913

Poerschman J, Rauschen S, Langer U, Augustin J, Górecki T (2009) Fatty acid patterns of genetically modified Cry3Bb1 expressing Bt-maize MON88017 and its nearisogenic line. J Agr Food Chem 57:127-132

Poerschmann J, Gathmann A, Augustin J, Langer U, Górecki T (2005) Molecular composition of leaves and stems of genetically modified $B t$ and near-isogenic non- $B t$ maizecharacterization of lignin patterns. J Environ Qual 34:1508-1518

R Development Core Team (2006) R: a language and environment for statistical computing. R Foundation for Statistical Computing, Vienna, Austria. ISBN 3-900051-070, URL http://www.R-project.org

Romeis J, Bartsch D, Bigler F et al (2008) Assessment of risk of insect-resistant transgenic crops to nontarget arthropods. Nat Biotechnol 26:203-208

Saxena D, Stotzky G (2001) Bt corn has a higher lignin content than non- $B t$ corn. Am J Bot 88:1704-1706

Saxena D, Stotzky G (2002) Bt toxin is not taken up from soil or hydroponic culture by corn, carrot, radish, or turnip. Plant Soil 239:165-172

Saxena D, Flores S, Stotzky G (1999) Insecticidal toxin in root exudates from $B t$ corn. Nature 402:480

Sims SR, Holden LR (1996) Insect bioassay for determining soil degradation of Bacillus thuringiensis subsp. kurstaki Cry1A(b) protein in corn tissue. Environ Entomol 25:659664

Tapp H, Stotzky G (1998) Persistence of the insecticidal toxin from Bacillus thuringiensis subsp. kurstaki in soil. Soil Biol Biochem 30:471-476

Tarkalson DD, Kachman SD, Knops JMN, Thies JE, Wortmann CS (2008) Decomposition of Bt and non-Bt corn hybrid residues in the field. Nutr Cyc Agroecosys 80:211-222

Taylor BR, Parkinson D, Pearsons WFJ (1989) Nitrogen and lignin content as predictors of litter decay rates: a microcosm test. Ecology 70:97-104

VDLUFA (1976) Methodenhandbuch Bd. III. Die Chemische Untersuchung von Futtermitteln. VDLUFA, Speyer 
Zwahlen C, Hilbeck A, Gugerli P, Nentwig W (2003) Degradation of the Cry1 Ab protein within transgenic Bacillus thuringiensis corn tissue in the field. Mol Ecol 12:765775
Zwahlen C, Hilbeck A, Nentwig W (2007) Field decomposition of transgenic $B t$ maize residue and the impact on nontarget soil invertebrates. Plant Soil 300:245-257 